\title{
Local Institutions and Social Capital for Agrotourism Development: A Case Study in Sanda Village, Tabanan-Bali
}

\author{
M. A. Sutiarso', K. T. P. Arcana ${ }^{2}$, N. A. Suprapto 3 \\ ${ }^{123}$ The International Institute of Tourism and Business, Bali \\ \{*agussutiarso63@gmail.com\}
}

\begin{abstract}
Community-based agrotourism development is believed to provide benefits for the welfare of farmers, as it provides employment opportunities and seeks community. As one of the economic empowerment efforts of the villagers, agrotourism development in Sanda Village requires support and efforts to optimize the resources, both human resources and natural resources. This research aims to analyze the institutional role of community and social capital of farmers in Sanda village for agrotourism development. Data obtained through observation, field interviews and library studies, then analyzed and presented in qualitative descriptive form with interpretation as a base pole. The results showed that the existence of local institutions in Sanda village (Subak, Pokdarwis, PKK, Karang Taruna, Bumdes) can be used as a means and contribute in realizing agrotourism business independence. The social capital of Sanda village farmers is able to strengthen mutual trust and mutual respect in the bonds of synergistic business activities.
\end{abstract}

Keywords: agrotourism; farmers; Sanda Village; Community-based

\section{Introduction}

Agrotourism around the world has become a global tourism trend. Over the past two decades, there has been a significant shift away in the interest of tourist destinations. This can be seen from the shift in the motivation orientation for tourist visits from mass tourism to individuals/small group visits with local daily life attractions. Tourists tend to want to carry out various tourist activities in the location that is relatively quiet and natural, has clean and fresh air, and has interesting and unique attractions. These characteristics are generally possessed by rural areas[2]-[8]. The development of agrotourism will create job opportunities because this business can absorb laborers from rural communities so that it can hold back or reduce the current increasing flow of urbanization. The benefits that can be obtained from agrotourism include preserving natural resources, preserving local technology, and increasing the income of farmers/surrounding communities[10].

The concept of sustainability is an important factor in the development of agrotourism. One of the principles of sustainable agrotourism development is local community participation. Local institutions in rural areas have a very important role to play in mobilizing local community participation[3]. Local communities, especially indigenous people who live in tourist areas, are one of the key players in tourism because they are the ones who will provide most of the attractions as well as determine the quality of tourism products. The involvement of local communities in the development of an agrotourism area to improve the welfare of local communities and alleviate poverty can be categorized as local economic 
development. This strategy needs to involve rural communities directly in the planning, implementing, evaluating, and monitoring of the development in their region.

The key to success in the development of a society is social capital. The components of social capital, i.e. mutual trust, cooperation networks, and norms, are considered to have a positive relationship with regional economic growth. Social capital is also a condition that must be met in the development process. Various problems and irregularities that occur in various countries are caused by underdeveloped social capital in society. Weak social capital will reduce the spirit of mutual cooperation, exacerbate poverty, increase unemployment, intensify criminal acts, and hinder any efforts to improve public welfare[6]-[11]. In this study, the researcher analyzed the role of social capital and constructed the role of local institutions in Sanda village for agrotourism development.

\section{Methodology}

The employed techniques of data collection in this study were observation and interviews with farmers selected purposively. The data were collected and recorded in detail then sorted and focused on important things to be analyzed based on points according to the research objectives. The data were then processed and presented in a qualitative descriptive form with the interpretation process as the main pillar[9].

\section{Result and Discussion \\ 3.1 The Potential of Farm-Based Agrotourism in Sanda Village}

The attraction of rice field farming in Sanda village is a potential that can be developed into agricultural education tours. Nowadays, parents and schools tend to choose to bring their children and students to visit educational tourist areas. One of the educational tours that are currently becoming a trend is to live in an agro-based tourism village by participating in all farmer activities in managing their farming business. The processing of traditional rice farming is one method in introducing students as the younger generation to the origin of food. As an effort to preserve local wisdom and as a medium of education for the younger generation, Sanda Village has the potential for agrotourism. Besides providing the traditional rice cultivation process, there are also coffee bean processing, ant-sugar production, sap processing, beekeeping, goat farming, and various fruit farming businesses such as bananas, mangosteens, oranges, thorny palms, and durians.

The farming business does not only serve as a food producer but also as a tourist attraction (agrotourism) which has proven to have a positive impact on society. A study conducted by Hamzah[4] in Peninsular Malaysia showed that agrotourism is useful in promoting sustainable rural development. Agrotourism can increase community social empowerment, strengthen social ties between communities, increase income, diversify economic activities, provide employment opportunities, and alleviate poverty. A study on agrotourism based on traditional rice farming in Pentingsari Tourism Village by Handayani[5] indicated that people who are directly and indirectly involved in agro-tourism can get economic benefits. Agrotourism in Pentingsari Village can increase the income of farmers and the surrounding community. Socio-cultural benefits can be enjoyed by all members of the community, both those involved in agrotourism and those who are not. These results also showed that agrotourism preserves local culture, reduces poverty, reduces unemployment, prevents urbanization, and maintains the environment. 


\subsection{Local Institutions and Social Capital for Agrotourism Development in Sanda Village}

Agricultural development basically includes the development and improvement of several factors, i.e. technology, natural resources, human resources, and institutions[7]. These factors constitute sufficient requirements to achieve the desired development performance. It means that if one or more of these factors are not available or are not in accordance with the required requirements, then the goal of achieving a certain desired performance will not be attained. For this reason, it is necessary to develop local farmer institutions based on the premise as follows. 1) The agricultural process requires strong human resources supported by infrastructure, equipment, credit, and so on; 2) Farmers' institutional development is more complicated than natural resource management because it requires supporting factors and production units; 3) Agricultural activities cover three sets, i.e. preparing inputs, converting inputs into products by labor and management efforts, and placing inputs as value; 4) Agricultural activities require support in the form of policies and institutions from central and local governments; and 5) The complexity of agriculture, which includes business and institutional units, makes optimal conditions difficult to achieve[1].

The farmer institutions in Sanda Village are the Subak Group (for rice plants), the Subak Abian Group (for coffee plants), the Goat Farmer Group, and the Trigona Beekeeping Group. The existence of this farmer institution is based on the cooperation carried out by farmers in Sanda Village in managing agricultural resources. This farmer joint activity group is believed as a facilitating factor in agricultural development because togetherness can make it more effective in achieving the shared-desired goals. In order to develop the potential of farming activities in Sanda village for agrotourism, one of the approaches taken is to proclaim the establishment of the tourism village. Through this tourism village, the development of Sanda Village no longer only relies purely on the agricultural sector but expands towards tourism activities in the agricultural sector. The government of Tabanan Regency has accommodated the establishment of this tourism village by issuing a Regent Decree which designated Sanda Village as a Tourism Village based on the Tabanan Regent Decree No. 180/309/03/HK \& HAM/2018. Based on this decree, a Tourism Awareness Group (in Indonesian: Kelompok Sadar Wisata (POKDARWIS)) in Sanda Village was formed as an embodiment of a community institution that became the driving element in supporting the creation of a conducive environment and atmosphere for tourism development in Sanda Village.

One of the keys to success in developing agrotourism in Sanda village is optimizing local community capacity through collaboration between community institutions. However, POKDARWIS in Sanda Village is still in the consolidation stage. There are still many things that need to be addressed, both in terms of organization and formulation of work programs. It is hoped that through this community-organizing process, the role of the local community will be seen in developing agrotourism in Sanda Village. Furthermore, this effort will be able to increase social capital by enhancing and strengthening relationships among people and by building trust and recognizing common interests. 


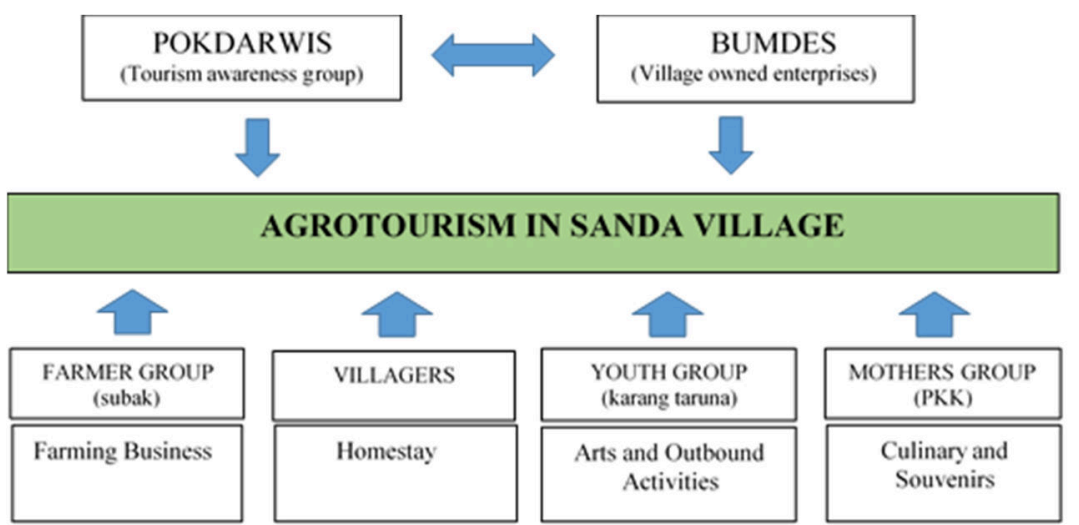

Fig 1. Model of Institutional Integration for Agrotourism Development in Sanda Village

Social capital has three important elements, i.e. trust, norms, and social networks. The social capital possessed by the people of Sanda Village, who are mostly farmers, is the main supporters for the development of agrotourism in Sanda Village. Trust is a form of someone's willingness to take risks with the reciprocity given. Trust that exists between individuals can have a good impact on the survival of society. Trust between people can be seen from how they interact with each other in fulfilling their needs. Trust between farmers, especially in the Subak Group in Sanda Village, is well-established. It can be seen from the arrangement of irrigation water. Farmers always obey the rules or directions given by the pekaseh (leader of the Subak Group). Farmers, who become the member of the Subak Group, have full trust in the management of the group and always support each other in terms of both financial management and other activities. The management of the Subak Group is transparent in carrying out the financial affairs, both incoming and outgoing funds for activities conducted by the Subak Group such as organizing odalan at Pura Subak or maintenance costs for irrigation channels. Farmers' belief in religious rituals (Hinduism) in Sanda Village is still strong and has been carried out from the past until now, both collectively and individually.

Norms are a set of rules that have been agreed upon and are expected to be obeyed by the community in a particular social entity. Norms are usually formed by the society where the norms are believed to be a limitation that can regulate their life patterns. Norms act as controls that can regulate society to behave according to mutual agreement. In Sanda Village, there are norms or rules in the form of awig-awig. In this awig-awig (written regulations that have been mutually agreed upon), it regulates the obligations of the members of the Subak Group and sanctions for those who do not comply. Furthermore, meetings in this group are one of the mechanisms and efforts to maintain communication between farmers. Meetings are held every three months to discuss planting plans, the use of varieties/seeds, the provision of production facilities (fertilizer), and financial affairs. Incidental meetings are also held if they have a problem or if the government launches programs related to their activities.

The network is something that is highly needed by someone in social life. The network possessed will have an impact on themselves and others. The network is also a relationship that a person has with other people. The key to the success of building social capital lies in people's ability to involve themselves in a network of social relationships. The extent of someone's social network can be described by how close they are to the networks they have and how these networks can help with the daily activities of the community concerned. The networks possessed by farmers in Sanda Village include their relationship with the 
government, in this case, the Agriculture Service or Public Works Service. Relations are also well-established with the people of Banjar, a traditional village. It can be seen in the participation of the people of Banjar in mutual cooperation in making ceremonial facilities at Pura Subak.

This study found that activities of local institutions that are based on written or unwritten rules can be used as an important stepping stone for the sustainability of a particular activity. The strong network of groups based on a rule and believed to be sustainable in kinship ties reflects the strong social capital from people initiating it. The possessed social capital must develop over time. Furthermore, relations with other parties must be also well-established so that it can increase the empowerment of the business being developed. The development of agrotourism requires specific capacities from local communities. The capacity of organizing resources (social and material) greatly determines the success of community-based agrotourism development.

In developing community-based agrotourism, community members must organize and operate the agrotourism business based on the rules, division of tasks, and authorities that they have agreed upon together. Resources, especially the farmland, remain the property of individual farmers. However, each of them can hand over the management of their assets to a group or management party they choose in exchange for a proportional profit. The development of agrotourism can be sustainable if it is economically profitable, always preserves natural resources and the environment, supports the maintenance of local culture, is equitable in the distribution of benefits and risks, involves various stakeholders, promotes cooperation and partnership, has a long-term perspective, and focuses on welfare.

Challenges in developing agrotourism in Sanda Village include 1) a lack of understanding of agrotourism activities by farmers and other tourism actors, 2) weak ability possessed farmers to communicate and take a commercial approach (marketing), 3) a lack of capital needed to develop basic agrotourism infrastructure, 4) the existence of unorganized sectors in the agrotourism industry, and 5) guarantee factors in which the management must ensure hygiene and provide basic requirements for tourists. The supports from all parties, i.e. the government, the private sector, universities, and the local community in developing agrotourism, are highly needed so that the desired goals can be achieved.

\section{Conclusion}

The conclusions of this study are as follows. 1) Sanda Village has the potential for farming which can be developed into agrotourism, such as coffee plantations, cocoa plantations, rice fields, cattle farming, and goat farming. The processing of agricultural products is also an interesting agrotourism attraction as an educational tour while, at the same time, preserving traditional wisdom. 2) The existence of local institutions in Sanda Village has become a necessity to improve the standard of living and dignity. This local institution must be constituted as a means of realizing hope. It is expected that effective institutional involvement for the development of agrotourism will be able to contribute to increasing self-reliance. 3) Social capital is used by someone to be able to live by socializing. The social capital in Sanda Village is able to strengthen mutual trust in the community. The actualization of social capital for the development of agrotourism in Sanda Village will actually be able to create mutual respect between individuals or groups in the synergized business activities. 
Recommendations that can be given are as follows. 1) Existing social capital must be strengthened by support from other parties so that it can increase institutional capacity and increase the empowerment of the businesses engaged in developing agrotourism in Sanda Village. 2) It needs support from various parties, especially the government and universities in the form of assistance and facilitation for community-based agrotourism development because the determinants of this success depend on the commitment and capacity of the involved community.

\section{References}

[1] Anantanyu, S. ,"Kelembagaan Petani: Peran dan Strategi Pengembangan Kapasitasnya," SEPA Vol. 7 No. 2 : 102-109, 2011.

[2] Boudy, J. F., "Interrelationships between Tourism and Agriculture," Tourism Recreation Research. 16 (1): 64-65, 2001.

[3] Damanik, J. dan H. F. Weber, Perencanaan Ekowisata - Dari Teori ke Aplikasi, Yogyakarta: Pusat Studi Pariwisata UGM, 2006.

[4] Hamzah, A., "Socio-economic Impact Potential of Agrotourism Activities on Desa Wawasan Nelayan Community Living in Peninsular Malaysia," African Journal of Agricultural Research. Vol 7 No.32: 4581-4588, 2012.

[5] Handayani, S. M., "Agrowisata Berbasis Usahatani Padi Sawah Tradisional Sebagai Edukasi Pertanian (Studi Kasus Desa Wisata Pentingsari)," Jurnal Habitat. Vol.27 No.3: 133-138, 2016.

[6] Inayah, "Peran Modal Sosial dalam Pembangunan," Jurnal Pembangunan Humaniora. Vol 12 No 1: 43-49, 2012.

[7] Pakpahan, A., "Kerangka Analitik untuk Penelitian Rekayasa Sosial: Perspektif Ekonomi Institusi," Prosiding Patanas Evolusi Kelembagaan Pedesaan. Disunting oleh Effendi Pasandaran dkk. Pusat Penelitian Agro Ekonomi. Bogor. Hal 1-18, 1989.

[8] Sharpley, R., Tourism and Leisure in The Countryside. Huntingdon UK: ELM Publications, 1997.

[9] Strauss, A. dan J. Corbin, Dasar-Dasar Penelitian Kualitatif. Yogyakarta: Pustaka Pelajar, 2003.

[10] Subowo, "Agrowisata Meningkatkan Pendapatan Petani," Warta Penelitian dan Pengembangan Pertanian Indonesia. Vol 24 No 1: 13-16, 2002.

[11] Vipriyanti, N. U., Modal Sosial dan Pembangunan Wilayah. Malang: Universitas Brawijaya Press, 2011. 